\title{
ETHICAL DILEMMAS EXPERIENCED BY NURSES PRESENTED IN NURSING PUBLICATIONS
}

\author{
Maria Adelane Alves Monteiro ${ }^{1}$ \\ Régia Christina Moura Barbosa² \\ Maria Graziela Teixeira Barroso ${ }^{3}$ \\ Neiva Francenely Cunha Vieira ${ }^{4}$ \\ Ana Karina Bezerra Pinheiro ${ }^{4}$
}

Monteiro MAA, Barbosa RCM, Barroso MGT, Vieira NFC, Pinheiro AKB. Ethical dilemmas experienced by nurses presented in nursing publications. Rev Latino-am Enfermagem 2008 novembro-dezembro; 16(6):1054-9.

This systematic literature review used nursing studies about "ethics" published in the SCIELO database. The objective was to identify the ethical dilemmas of nursing, based on a literature review of nursing publications between 2002 and 2006. Forty publications were found, of which seventeen were selected. The analysis of the articles permitted the organization of the following categories: ethics, the health system and nursing practice; ethics and nursing teaching-learning; ethics and nursing care. We noticed that the authors attributed a multidimensional approach to ethical issues. However, we considered it necessary to pay closer attention to the ethical aspects involved in nursing practice. There is a clear need for further studies, showing new ethical dilemmas experienced by nurses, so that they can contribute to a change in attitude, with outcomes for professional practice.

DESCRIPTORS: ethics; nursing; ethics, nursing

\section{DILEMAS ÉTICOS VIVENCIADOS POR ENFERMEROS Y PRESENTADOS EN PUBLICACIONES DE ENFERMERÍA}

Se trata de una revisión sistemática de la literatura, realizada en artículos del área de la enfermería, contenidos en el banco de datos SCIELO, y que abordaron el tema "ética". El estudio tuvo como objetivo identificar los dilemas éticos de la enfermería a partir de una revisión de la literatura en publicaciones sobre esa área, en el período de 2002 a 2006. Se localizaron cuarenta publicaciones, de las cuales fueron seleccionadas diecisiete. El análisis de los artículos permitió la organización de las categorías en: ética, el sistema de salud y la práctica de enfermería, ética y la enseñanza-aprendizaje en la enfermería y, ética y el cuidado de enfermería. Se percibió que los autores realizaron, sobre las cuestiones éticas, un abordaje multidimensional, entretanto, se consideró necesario, en este estudio, dar mayor atención a los aspectos éticos que se encuentran frecuentemente en la práctica de enfermería. Quedó clara la necesidad de realizar otros estudios que pongan en evidencia nuevos dilemas éticos vivenciados por enfermeros, en el sentido de contribuir para el cambio de actitud, que implicaría en mejorar la calidad de la práctica profesional.

DESCRIPTORES: ética; enfermería; ética de enfermería

\section{DILEMAS ÉTICOS VIVENCIADOS POR ENFERMEIROS APRESENTADOS EM PUBLICAÇÕES DE ENFERMAGEM}

Trata-se de revisão sistemática da literatura, realizada em artigos da área da enfermagem, contidos no banco de dados SCIELO, e que abordaram o tema "ética". Teve como objetivo identificar os dilemas éticos da enfermagem a partir de revisão de literatura em publicações da área, no período de 2002 a 2006 . Localizouse quarenta publicações, das quais foram selecionadas dezessete. A análise dos artigos permitiu a organização das categorias: ética, o sistema de saúde e a prática de enfermagem, ética e o ensino-aprendizagem na enfermagem, ética e o cuidado de enfermagem. Percebeu-se que os autores atribuíram às questões éticas abordagem multidimensional, no entanto, considerou-se, aqui, necessária maior atenção a respeito dos aspectos éticos que permeiam a prática de enfermagem. Ficou clara a necessidade de mais estudos que evidenciem novos dilemas éticos vivenciados por enfermeiros, no sentido de contribuir para mudança de atitude, implicando na qualidade da prática profissional.

DESCRITORES: ética; enfermagem; ética de enfermagem

Universidade Federal do Ceará, Brazil:

${ }^{1}$ RN, M.Sc. in Community Health Nursing, e-mail: adelanemonteiro@hotmail.com; ${ }^{2}$ RN, M.Sc. in Community Health Nursing, Nurse at Maternidade Escola Assis Chateaubriand; ${ }^{3}$ RN, Full Professor, Faculdade de Farmácia, Odontologia e Enfermagem; ${ }^{4}$ Ph.D. in Nursing, Faculty, Faculdade de Farmácia, Odontologia e Enfermagem. 


\section{INTRODUCTION}

$\boldsymbol{H}$ uman beings face several threats this millennium, including nuclear and ecological hazards, collapse of the global economy, drugs, AIDS, etc. Science and the modern techniques produce qualitative changes in the way men act. The new technologies give men extreme power, and they become the object of their techniques. This becomes a threat demanding a new ethical design for our time ${ }^{(1)}$.

With modern times, applied ethics starts referring to bioethics, business ethics, and media ethics among others. However, human condition needs to develop a new ethic or an ethics for the future, complex and based on human existence. This is the ethics of complicity, complexity, and (com) passion, responsibility, (re) link/integration, understanding, solidarity, care, and love ${ }^{(2)}$.

On the other hand, all these changes contribute to the excessive use of the word ethics, twisting its original meaning or making its use common, leading to the decrease in its importance. Therefore, there is the need to question ethics today, with the fast and disorganized development faced by society, since we live in a time full of contradictions and the world is in constant change, and it is difficult to know where society is heading to ${ }^{(2)}$.

In this sense, the contents discussed in the schools and universities and teaching have to follow this development, since when professionals act in this reality, they face situations that involve ethical issues. In nursing, which is a science for human care, it is essential to reflect upon these issues since nurses are frequently facing ethical dilemmas in their every day activities, and there are differences between the theory and the practice.

Nursing has its activities based on principles and guidelines from the Ethical Code of Nursing Professionals. Nursing Councils have to supervise the professional work, including issues involving professional ethics, as well as to guide the formation of ethical committees and to support the performance of their role in hospitals.

Even with defined codes, law, and principles, it is a challenge to perform the nursing practice, because the references do not follow this development of things and of the world, and the contents do not approach the important ethical dilemma that are present in the routine performance of health activities.

Acknowledging this dilemma may be understood as an important step in the formation of ethical individuals since, many times, the conflicts, problems or doubts are not noticed. Either because they are not seen or people are indifferent to them. Problematizing the routine, noticing the difficulties, contradictions, and posing questions are the first step to talk about ethics ${ }^{(3)}$.

In this sense, the present study aims to identify the ethical dilemmas of nursing from the review of the literature in publications of the field from 2002 to 2006.

\section{METHODS}

Retrospective systematic review of the literature ${ }^{(4)}$ conducted from 2002 to 2006, as of articles of the nursing field approaching the "ethical" issue. Bibliography was taken from a survey conducted in the internet, at BVS/BIREME (Virtual Health Library of the Latin American and Caribbean Center for Health Information), using SCIELO (Scientific Electronic Library Online), as one of the main data base.

Indexed Brazilian journals were investigated in this data base using the key words: ethics and nursing. To obtain an updated view of the ethical issues involved in the practice of nursing professionals, the articles of the last five years approaching the issue were selected. Studies were completely searched for, read and assessed according to the script made of data with the characteristics of the study and to the ethical issues raised. Ethical aspects approached were raised in the selected articles and the empirical characteristics were interpreted and organized. Analysis was performed comparing the ethical dilemmas found and that reflected upon nursing practice, based on the literature.

\section{RESULTS}

Initially, forty publications were found, and 17 were selected because they met the goals of the study. Almost half of the findings corresponded to reflection studies (Table 1 ).

We saw that the number of articles found approaching ethical problems of the nursing routine was limited, considering that the international scientific production, in the same period, was three times higher. However, if we take into account the amount of indexed 
journals in these data bases, we may realize that this difference was not that considerable. There was also agreement between the studies approached by the studies of other countries and those of the Brazilian literature.

Among the main problems raised by the surveys were issues such as dehumanization in patients' care, as well as not respecting their rights, lack of access to health services, and nursing working relations and conditions together with the authoritarian relationship that is part of the education practice. We have identified that Philosophy and the principles of the health system, as well as the way services are organized are factors that contribute to the onset of ethical dilemmas. Nursing practice, inserted into this context, is vulnerable to the conflicts that may occur, requiring a basis to solve the issues that should be discussed since the start of professional education.

Table 1 - Demonstration of the studies on ethics in the nursing field in the last 5 years. Scielo, 2006

\begin{tabular}{|c|c|c|c|c|}
\hline$\#$ & Year & Data collection method & Study subjects & Surveyed place \\
\hline 1 & 2005 & Theoretical -reflective article & - & - \\
\hline 2 & 2004 & Photos by patients & In-Patients & School Hospital \\
\hline 3 & 2005 & Observation and interview & Health Professionals & Care nucleus of the university \\
\hline 4 & 2004 & Interview & Health Professionals & Family Health Program \\
\hline 5 & 2006 & Interview & $\begin{array}{c}\text { Nursing Managers and members from the } \\
\text { Nursing Ethical Committee }\end{array}$ & Hospital \\
\hline 6 & 2005 & Theoretical -reflective article & - & - \\
\hline 7 & 2005 & Theoretical -reflective article & - & - \\
\hline 8 & 2004 & Theoretical -reflective article & - & - \\
\hline 9 & 2003 & Theoretical -reflective article & - & - \\
\hline 10 & 2003 & Focus group and interview & Students from the nursing course & University Nursing course \\
\hline 11 & 2003 & Bibliographical survey & - & - \\
\hline 12 & 2003 & Free observation and interview & Women with breast cancer & Outpatient ward \\
\hline 13 & 2002 & Theoretical -reflective article & - & - \\
\hline 14 & 2002 & Theoretical -reflective article & - & - \\
\hline 15 & 2002 & Interviews & Nurses & Hospitals \\
\hline 16 & 2002 & Theoretical -reflective article & & - \\
\hline 17 & 2002 & Bibliographical survey & - & - \\
\hline
\end{tabular}

\section{DISCUSSION}

The main issues raised during the investigation led to the design of three categories discussed next: ethics, health system and the nursing practice, ethics and nursing teaching-learning, ethics and nursing care.

Ethics, the health system and the nursing practice

The ethical aspects to be discussed in this category are related with the practice the nursing professionals according to the national health system.

Institutionalization of the health system of the country is a change in the health care practice demanding ethical changes in professionals, managers and users.

The construction of the National Health System (SUS) in Brazil implies an ethical change not only with a new technical-care team, but also with a new working process marked by ethical and human practice connected with the practice of citizenship ${ }^{(5)}$. The new guideline of the care model imposes the gradual and increase introduction of a network of care whose organization demands a complex structure of community service together with land, cultural and social resources. In this sense, the radical task of building a new health action is set, leading to a break in paradigm, concept and ethics ${ }^{(5)}$.

Nursing is inserted in these contexts and experiences a paradigm crisis in its practice, since professionals are still working with a culture based on the hegemonic model of health, which focus on the complaint -behavior and is guided by poor clinics, that reproduces the medical model.

There is the need to change professional behavior, which should be guided not only to treat disease, but to contribute for the adoption of attitudes that can improve the health profile of clients and their families. Therefore, we acknowledge that the present moment demands changes in the work dynamics, and in the interaction service/professional/client ${ }^{(6)}$. 
However, all these proposals are in contradiction regarding the idealized view and the working conditions faced by the nursing staff: low salaries; work overload, accumulation of jobs, and double or even triple shifts; poor material resources, and lack of human resources; unsafe workplace; involvement with disease and death, and also difficulties of the nursing team to communicate and to relate with the medical team ${ }^{(3)}$. The interpersonal relationship among professionals and the service is intermingled by asymmetric relationships with features of authoritarianism and submission. This hierarchical model, together with working conditions contributes to the lack of humanization of nursing care.

Brazilian studies, in agreement with foreign studies, identified that health professionals pointed out ethical problems regarding the members of the working team as more important than those from the relationship with users and their families, both in primary, secondary, and tertiary care ${ }^{(7-8)}$.

It is worth mentioning that the National Health System takes up the ethical commitment of developing a health promotion policy, based on integrality and participative management and one of its axes is the work relations ${ }^{(9)}$

The Brazilian Health System still presents weaknesses that may lead to ethical problems, which are also present in developed countries. We highlight here those related with the difficulties within different levels of health care, to the access to services, to complementary procedures, both for out-patients and in hospital patients and concerning drug supply ${ }^{(10)}$

Nurses, working in care, face this reality in their routine. They see the suffering the population they treat go through and they understand how humiliating and cruel this situation is, and that they deserve nursing attention as professionals and also as human beings.

We must remember that ethical problems from the health system present a direct relationship with the ethics in service management. Usually, health services are managed by nurses, thus, nursing practice, as a management, must be rearranged looking for proposals based on ethical and democratic principles focusing on the work process, on professionals and clients. This is participative management of health services, based on dialogue and understanding health workers and clients as subjects $^{(11)}$.
From what was said, we consider that nursing must feel responsible for the current health situation of the country and nursing must acknowledge the important role that it plays in making the new health system concrete, which is a challenge in current days, because of its humanitarian and ethical philosophy.

Ethics and nursing teaching-learning

Among ethical issues raised in the articles of the teaching field, those related with the difficulties in the professor-student relationship are highlighted, together with the paradox between teaching and practice.

The problems between professors and students were mentioned by students in their perception of the education process of the nursing course. This opportunity to express their ideas was based on the logic stemming from the Political Pedagogical Project (PPP). This is centered on the critical and reflective education with political quality of subjects that can work changing the reality. PPP is the collective expression of the desired school and the type of student that should be formed. It is an instrument of the intention of all that are part of the school, thinking about the educational role and its relation with society. All this process aims at offering quality education in the intellectual, cultural, social, ethical, and political perspective ${ }^{(12)}$.

However, building the PPP is a challenge, because there are still limits on the professor-student relationship, which is many times an authoritarian relationship. Professors resist these types of policies and adopt a repressive behavior regarding students' opinions, not allowing them to have a reflective action and therefore, preventing critics to be built.

New ethical and professionals competencies are therefore necessary to those teaching. Among them, it is necessary to: follow the development of learning, be able to work on a team, be part of the school's administration, inform and involve parents on the process, use new technologies and face duties and ethical dilemmas of the profession.

To that end, it is necessary to understand the professor-students relationship going beyond the condition of the one who teaches and the one who learns. Professors and students are subjects built in history. This educational relationship, involving educator-students can only have a concrete meaning when it is understood as a social practice, assuming a world view ${ }^{(12)}$. 
Regarding the content that must be present in the discussions between professors and students, we see the need to change both the content and the practice, dependent on the transformation flow of the reality. This is what supports the construction of a teaching and care project built from health needs and based on ethical principles, because with the several changes experienced by society, there is a clear paradox between teaching and action. The graduation course demands a broader ethical education, and there must be space for discussion of clinical cases regarding ethics and the deep study of the Code of Ethics ${ }^{(12)}$. Thus, reflection and respect for values will be possible by developing ethical awareness of students.

Ethics and nursing care

To ethically take care of the other is an attitude that leads to reflection. Several issues in this sense have been approached by the articles, since care is the essence of the nursing profession. When taking care of patients, professionals must see them as human beings, with their needs affected, and therefore being fragile, deserving respect and attention. However, the development of nursing work is compared to the development process of society (dehumanization), leading to an uninvolved care. Lack of care and incorrect care are hazardous to people and are directly related with lack of ethics ${ }^{(13)}$.

Ethical attitude of professionals with patients is present every time they see their clients as people just like them, who need to be heard and understood so that there can be interaction and then, effective care. Professionals must respect their rights and must practice self-care to encourage autonomy and selfesteem of those they care for ${ }^{(13)}$.

Patients are entitled to know the nature and the objectives of the diagnoses, preventive and therapeutic procedures they will go through as well as how invasive they are, length of treatment, benefits, adverse effects, and the possible physical, psychological, economical and social risks. Facing these situations require a solidarity relationship, with mutual growth among peers that want to become subjects $^{(3,14)}$.

Thus, nursing behavior must be in the sense of protect these rights, however, we still see situations where there is no respect to the users' autonomy and where lack of information to patients and their families prevail. Lack of dialog, information, or insufficient information is one of the strongest reasons in patients' justification for not being able to take part in the decision making process of their treatment, as well as in the care or planning of their care ${ }^{(3,15)}$.

The Code of Ethics of Nursing Professionals recommends in articles 17, 18 and 20, that nurses responsibilities and duties are: to give proper information and explanation to the person, family, or collectivity regarding one's health, the treatment, and nursing care given; regarding one's rights, possible risks, benefits and problems that may occur; respect and acknowledge a person's or their legal representative rights to decide on their health, treatment and well being ${ }^{(15-16)}$.

Specific situations, such as care of children, adolescents, elderly, performing surgeries and informing severe diagnoses, which suggest a threat to life, can lead to conflicts that are routinely experienced by nurses ${ }^{(17)}$. These conflicts are also seen in surveys abroad and present ethical issues such as secrecy and confidentiality, violence, abuse and sexual abuse, social rights, demanding attitudes from health professionals that are not supported by the traditional and hegemonic ethics, so they need to find bases, documentation, consultation and, above all, bioethical reflection ${ }^{(18)}$.

We see how much lack of ethics and its implications may be present on the everyday life of nurses, and they cannot be distant from the attitudes that correspond to the non compliance to patients' rights and the severe disrespect to human beings, which hinders the guidelines of the nursing care practice.

Therefore, it is necessary a re-humanization of nursing care, so that it works based on interaction, affection, tenderness, and love, linking the technical value to the ethical one, matching reason and heart. To that end, the integration of the spiritual dimension to the every day activities of professionals is essential as a determinant factor for their work, as well as an inducer for better quality of personal and professional life of nurses ${ }^{(19)}$.

\section{FINAL CONSIDERATIONS}

With so many changes occurring in society, nursing professionals are involved in ethical dilemma in the every day lives, taking part both passively and actively in actions concerning human beings is evident. 
From this study, we consider that despite its multidimensional approach (political, social, cultural, and spiritual) that has been attributed to the theme by researchers, a reflection is also necessary, and the ethical aspects guiding nursing practice should be thought about. Professionals should not be alienated from the ethical issues they face. New studies must be designed to show the main ethical problems faced, so that nurses may be made aware to the changes in attitude with implications in the quality of professional practice.

We conclude that this issue must be part of the discussion of all involved: students, professionals, professors, clients so that we understand and build a new ethics based on human care, which is the essence of nursing.

\section{REFERENCES}

1. Russ J. Pensamento ético contemporâneo. $3^{a}$ ed. São Paulo: Paulus; 2003.

2. Boff L. Ética e moral: a busca dos fundamentos. Petrópolis: Vozes; 2003

3. Lunardi VL, Lunardi Filho DW, Silveira RS, Soares NV, Lipinski JM. O cuidado de si como condição para o cuidado dos outros na prática de saúde. Rev Latino-am Enfermagem [periódico na Internet] 2004 [citado 2006 jun 13]; 12(6): [cerca de 8 p.]. Disponível em: http://www.sicelo.br/ scielo.php?script=csi_artex\&pid=s0104$11692004000600013 \&$ Ing $=p t \& n r m=i s s o$.

4. Castro AA. Revisão sistemática com ou sem metanálise. São Paulo: AAC; 2001.

5. Zoboli ELCP, Fortes PAdeC. Bioética e atenção básica: um perfil dos problemas éticos vividos por enfermeiros e médicos do Programa Saúde da Família, São Paulo, Brasil. Cad. Saúde Pública [periódico na Internet] 2004 [citado 2006 jun 13]; 20(6): [cerca de 11 p.]. Disponível em: http://www.sicelo.br/ scielo.php?script =csi_artex\&pid=s 0102 $31 \times 2004000600028 \&$ Ing $=p t \& n r m=$ isso.

6. Queiroz MVO, Jorge MSB. Concepções de promoção da saúde e atuação dos profissionais que cuidam da criança. Acta Paul Enferm 2004; 17(1): 31-5.

7. Wagner N, Ronen I. Ethical dilemmas experienced by hospital and community nurses: an Israeli survey. Nurs Ethics 2002; 3(4): 58-62.

8. Van Der Arend AJG, Remmers-Van Der Hurk HM. Moral problems among dutch nurses: a survey. Nurs Ethics 2002; 6(2):164-8.

9. Campos GW, Barros RB, Castro AM. Avaliação da política nacional de promoção da saúde. Ciênc Saúde Coletiva 2004; 9(3): 745-9.

10. Viens DC. Moral dilemmas experienced by nurse practitioners. Nurse Pract Forum 2002; 5 (1): 69-75.

11. Spagnol CA. (Re)pensando a gerência em enfermagem a partir de conceitos utilizados no campo da Saúde Coletiva. Ciênc Saúde Coletiva [periódico na Internet] 2005 [citado 2006 jun 13]; 10(1): [cerca de 10 p.]. Disponível em: http:/ / www.sicelo.br/scielo.php?script=csi_artex\&pid=S1413$81232005000100019 \&$ Ing $=p t \& n r m=$ isso.

12. Mishima SM, Chirelli MQ. A formação do enfermeiro crítico-reflexivo no curso de enfermagem da Faculdade de Medicina de Marília - FAMEMA. Rev Latino-am Enfermagem [periódico na Internet] 2002 [citado 2005 mar 20]; 11(5): [cerca de 13p.].Disponível em: http://www.sicelo.br/ scielo.php?script=csi_artex\&pid=s 0104 $11692003000500003 \&$ Ing $=p t \& n r m=i s s o$.

13. Pinheiro PN, Vieira NFC, Pereira MLD, Barroso MGT. O cuidado humano: reflexão ética acerca dos portadores do HIV/AIDS. Rev Latino-am Enfermagem [periódico na Internet] 2005 [citado 2006 jun 13]; 13(4): [cerca de 9 p.]. Disponível em: http://www.sicelo.br/ scielo.php?script=csi_artex\&pid=s 0104 $11692005000400016 \&$ Ing $=p t \& n r m=i s s o$.

14. Arantes SL, Mamede MV. A participação das mulheres com câncer de mama na escolha do tratamento: um direito a ser conquistado. Rev Latino-am Enfermagem [periódico na Internet] 2003 [citado 2005 mar 20]; 11(1): [cerca de 10p.]. Disponível em: http://www.sicelo.br/scielo.php?script=csi_artex\&pid=S0 104-11692003000100008\&Ing =pt\&nrm=isso.

15. Pupulim JSL, Sawada NO. O cuidado de enfermagem e a invasão de privacidade do doente: uma questão ético-moral. Rev Latino-am Enfermagem [periódico na Internet] 2002 [citado 2005 mar 20]; 10(3): [cerca de 8 p.]. Disponível em: http://www.sicelo.br/scielo.php?script=csi_artex\& $\mathrm{pid}=$ S0104-11692002000300018\&Ing = pt\&nrm=isso.

16. Código de Ética dos Profissionais de Enfermagem. Resolução COFEN n 311/2007. Fortaleza (CE): Conselho Regional de Enfermagem do Ceará; 2007.

17. Cameron ME. Older persons' ethical problems involving their health. Nurs Ethics 2002; 10(3): 32-5.

18. Freitas GFde, Oguisso T, Merighi MAB. Ethical events in nursing: daily activities of nurse managers and nursing ethics commitee members. Rev Latino-am Enfermagem [periódico na Internet] 2006 [citado 2006 jun 13]; 14(4): [cerca de 8 p.]. Disponível em: http://www.sicelo.br/scielo.php ?script $=$ csi_artex\&pid $=$ S0104-1169200600040005\&Ing $=$ pt\&nrm $=$ isso.

19. Mendes IAC, Trevisan MA, Ferraz CA, Fávero N. The rehumanization of the executive nurse's job: a focus on the spiritual dimension. Rev Latino-am Enfermagem [periódico na Internet] 2002 [citado 2005 mar 10]; 10(3): [cerca de 6 p.]. Disponível em: http://www.sicelo.br/scielo.php?script=csi_artex\&pid= S0104-11692002000300014\&Ing =pt\&nrm=isso. 